\title{
A NOTE ON BIOMPHALARIA STRAMINEA (DUNKER, 1848) FROM MANAUS, STATE OF AMAZONAS, BRAZIL
}

\author{
Frederico S. Barbos $x$
}

\begin{abstract}
Biomphalaria straminea (= centimetralis), an important intermediate host of Schistosomiasis in Brazil, has large geographical distribution. It is known from Venezuela, Guianas and Brazil, reaching south to about $20^{\circ}$ latitude.
\end{abstract}

In Northeastern Brazil $B$. straminea is a most important vector of the disease. It is the only vector known it the State of Ceará as well as in most of the territories of the State of Pernambuco, Paraiba and Rio Grande do Norte.

$B$. straminea is also known from Northern Brazil. It occurs in several areas of the carboniferous formation of the Amazon basin (Sioli, 4). This species was incriminated as the vector of Schistosomiasis in a limited focus localized in Belterra, Fordlandia, state of Pará.

The material used in the current paper was received from Dr. Mario Morais of the "Instituto Nacional de Pesquisas da Amazonia" In September 1965. It consisted of 56 snails from which 42 were alive. Collected outside the town of Manaus, State of Amazonas, Brazil, the snails, were found in lake Rei in center of Careiro and in a small "igarapé" afluent of the "Igarapé" Cachoeirinha.

The snails, kept in tanks, were used for observations on morphology, crossing experiments and exposition to the infection with a Northeastern strain of Schistosoma mansoni.

Prior to the experiments all the snails were exposed to sun light during few hours for several days and none of them shed cercariae of the mansoni type.

six snails were preserved and the animals dissected. The morphology of the animals dissected, particularly genitals, kidney and radula, was the same as compared with typical specimens of $B$. straminea from several places in Brazil.

Crossing experiments were performed between pigmented snails from Manaus and an albino strain of $B$. straminea from Quixeramobim (State of Ceará, Northeastern Brazil) according to techniques previously described (Barbosa et al., 1). Two couples were used. Each couple (Manaus $x$ Quixeramobim) was put to mate in a small glass container for 30 days. After that period the albino snails were isolated from its partners and followed during another 30 days. Results of those experiments show that the two snails are conspecific. In both experiments pigmented snails were produced exclusively. Couple 1 produced 69 pigmented F1 snails while couple 2 produced 94 snails of the same type. No albino snails were obtained during the 30 days of observation. Hybrids obtained were fertile and produced prosperous colonies.

Snails from Manaus were exposed to miracidia of a Northeastern strain of $\boldsymbol{s}$. mansoni. Each snail was exposed to 5 miracidia, and examined daily for cercariae after the 20 th day of the infection Negative results were obtained of the 
exposition of 15 snails originally colected in Manaus plus 86 snails of a laboratory reared progeny. A highly suscepzible strain of the known intermediate host of $S$. mansoni, Biomphalaria glabrata, was used as control in the above experiment.

Other snail specimen from Manaus was exposed to $h$ gh unrecorded number of miracidia of $S$. mansoni. The snail was fixed in Boun's fluid after 24 hours of the exposition and the anterior part of tie animal sectioned and stained w.th haematoxilin-eosin. Tissue reactions were obsirved around all the penetrating miracidia denotating the well known process of destruction of the parasite in resistant snails (Barbosa et al., 1) .

The possibil.ty of introduction of Schis- tosomiasis in Amazon region has been fully discussed by Soli (1953). He found $B$. straminea (= Tropicorbis pararyensis) only in areas of the carboniferous formation where the surface water is almost neutral. He concluded that there is little danger of the introduction of Schistosomiasis in the rest of the great area of the Amazon basin where waters are acid and the snails were not found.

Negat:ve attemps to infect the specimens of $B$. straminea from Manaus do not exclude the possibility of those snails to become adapted to other strain of $S$. mansoni. Evidence of local adaptation of a snail of $S$. mansoni was recently produced by Paraense \& Correa (2) in Southern Brazil.

\section{BIBLIOGRAPHY}

1 - BARBOSA, F.S. et al. Manual de Malacologia Médica - Fundação Gonçalo Moniz, Salvador, Bahia, 1966.

2 - PARAENSE, W.L. \& CCRREA, L.R. Susceptibility of Australorb's tenagophilus to infection with Schistosoma mansoni. Rev. Inst. Med. Trop. São Paulo, 5: 23-29, 1963.
3 - SIOLI, H. Schistosomiasis and Limnology in the Amazon Region. Am. J. Trop. Med. and Hyg., 2: 700-70\%, 1953.

4 - SIOLI, H. Limnologische Untersuchungen und Betrachtungen zur erstmaligen Entdeckung endemischer Schistosomiasis (Sch. mansoni) in Amazonasgebiet. Arch. F. Hydrobiol, 48: $1-23,1953$. 